\title{
Size distribution and mixing state of black carbon particles during a heavy air pollution episode in Shanghai
}

\author{
Xianda Gong ${ }^{1}$, Ci Zhang ${ }^{1}$, Hong Chen ${ }^{1}$, Sergey A. Nizkorodov ${ }^{2}$, Jianmin Chen ${ }^{1,3}$, and Xin Yang ${ }^{1,3}$ \\ ${ }^{1}$ Shanghai Key Laboratory of Atmospheric Particle Pollution and Prevention, Department of Environmental Science and \\ Engineering, Fudan University, Shanghai 200433, China \\ ${ }^{2}$ Department of Chemistry, University of California, Irvine, California 92697, USA \\ ${ }^{3}$ Fudan-Tyndall Center, Fudan University, Shanghai 200433, China \\ Correspondence to: Xin Yang (yangxin@fudan.edu.cn)
}

Received: 11 November 2015 - Published in Atmos. Chem. Phys. Discuss.: 16 December 2015

Revised: 19 April 2016 - Accepted: 20 April 2016 - Published: 29 April 2016

\begin{abstract}
A Single Particle Aerosol Mass Spectrometer (SPAMS), a Single Particle Soot Photometer (SP2) and various meteorological instruments were employed to investigate the chemical and physical properties of black carbon (BC) aerosols during a regional air pollution episode in urban Shanghai over a 5-day period in December 2013. The refractory black carbon (rBC) mass concentrations measured by $\mathrm{SP} 2$ averaged $3.2 \mu \mathrm{g} \mathrm{m}^{-3}$, with the peak value of $12.1 \mu \mathrm{g} \mathrm{m}^{-3}$ at 04:26 LT on 7 December. The number of BC-containing particles captured by SPAMS in the size range $200-1200 \mathrm{~nm}$ agreed very well with that detected by SP2 $\left(R^{2}=0.87\right)$. A cluster analysis of the single particle mass spectra allowed for the separation of BC-containing particles into five major classes: (1) Pure BC; (2) BC attributed to biomass burning (BBBC); (3) K-rich BC-containing (KBC); (4) BC internally mixed with $\mathrm{OC}$ and ammonium sulfate $\left(\mathrm{BCOC}-\mathrm{SO}_{x}\right)$; (5) $\mathrm{BC}$ internally mixed with $\mathrm{OC}$ and ammonium nitrate $\left(\mathrm{BCOC}-\mathrm{NO}_{x}\right)$. The size distribution of internally mixed $\mathrm{BC}$ particles was bimodal. Detected by SP2, the condensation mode peaked around $\sim 230 \mathrm{~nm}$ and droplet mode peaked around $\sim 380 \mathrm{~nm}$, with a clear valley in the size distribution around $\sim 320 \mathrm{~nm}$. The condensation mode mainly consisted of traffic emissions, with particles featuring a small $\mathrm{rBC}$ core $(\sim 60-80 \mathrm{~nm})$ and a relatively thin absolute coating thickness (ACT, $\sim 50-130 \mathrm{~nm}$ ). The droplet mode included highly aged traffic emission particles and biomass burning particles. The biomass burning particles had a larger rBC core $(\sim 80$ $130 \mathrm{~nm})$ and a thick ACT $(\sim 110-300 \mathrm{~nm})$. The highly aged traffic emissions had a smaller core $(\sim 60-80 \mathrm{~nm})$ and a very thick ACT $(\sim 130-300 \mathrm{~nm})$, which is larger than reported in
\end{abstract}

any previous literature. A fast growth rate $\left(\sim 20 \mathrm{~nm} \mathrm{~h}^{-1}\right)$ of $\mathrm{rBC}$ with small core sizes was observed during the experiment. High concentrations pollutants like $\mathrm{NO}_{2}$ likely accelerated the aging process and resulted in a continuous size growth of rBC-containing particles from traffic emission.

\section{Introduction}

Aerosols represent the largest uncertainty in estimating radiative forcing of atmospheric species, by strongly affecting the energy balance of the Earth by scattering and/or absorbing solar radiation (Pöschl, 2005), and influencing cloud formation (Jacobson, 2006). Emitted from incomplete combustion of fossil fuel and biomass (Bond et al., 2013), black carbon (BC) is a strongly light-absorbing carbonaceous material in aerosols, second to carbon dioxide as a contributor to positive radiative forcing (Ramanathan and Carmichael, 2008; Jacobson, 2001).

The physical (e.g., size distribution and morphology) and chemical (e.g., mixing state and composition) properties of ambient $\mathrm{BC}$ are very complex and are constantly changing in the atmosphere. For example, BC particles exposed to sub-saturated sulfuric acid vapor exhibit a marked change in morphology, characterized by a decreased mobility-based diameter but an increased fractal dimension and effective density (Zhang et al., 2008). By using electron tomography with a transmission electron microscope and three-dimensional imaging, Adachi et al. (2010) found that many BC particles have open, chainlike morphology even after being sur- 
rounded by organic matter, and are located in off-center positions within their host materials. China et al. (2013) analyzed the morphology of single $\mathrm{BC}$ particles using electron microscopy and classified them into four categories: $\sim 50 \%$ were embedded (heavily coated), $\sim 34 \%$ were partly coated, $\sim 12 \%$ had inclusions and $\sim 4 \%$ were bare. The organic coating is known to strongly affect the optical properties of the soot aggregates by acting as a lens that amplifies the absorption cross section of the BC core (Lack and Cappa, 2010; Shiraiwa et al., 2010). Schnaiter et al. (2005) observed amplification factors of the internally mixed BC of 1.8 to 2.1 relative to the specific absorption cross section of externally mixed BC. Zhang et al. (2008) observed that the internally mixed particles can increase their absorption efficiency by nearly two-fold and scattering efficiency by approximately ten-fold at $80 \%$ relative humidity relative to fresh particles. On the other hand, Cappa et al. (2012) and Lan et al. (2013) observed a limited enhancement due to the mixing state of ambient BC, suggesting that other factors may affect their absorption properties. Through coagulation and condensation, $\mathrm{BC}$ can form an internal mixture, which increases its cloud nucleation activity (Khalizov et al., 2009; Moffet and Prather, 2009). Most BC is removed from the troposphere via wet deposition with a short lifetime of 5 to 10 days (Kanakidou et al., 2005; Chung and Seinfeld, 2002).

Many measurement methods for refractory BC (rBC) particles have been developed and used in recent years (Petzold et al., 2013). Among them, the Single Particle Soot Photometer (SP2) has become increasingly recognized as a valuable tool for characterizing $\mathrm{rBC}$-containing particles (Stephens et al., 2003; Schwarz et al., 2006). SP2 can quantitatively measure the mass and determine the mixing state of an individual rBC-containing particle (Schwarz et al., 2010). Taylor et al. (2015) evaluated the capability of the SP2 to determine the particle mixing state with help of the concentric core/shell model. Liu et al. (2014) analyzed the size distribution and mixing state of $\mathrm{rBC}$ aerosols in London during winter time using the same technique. Furthermore, Moteki et al. (2014) identified two morphological types of the mixed rBC-containing particles as attached and coated, an important finding for understanding the climate impact of $\mathrm{rBC}$ particles. Recently, a soot particle aerosol mass spectrometer (SP-AMS) was developed to characterize rBC and nonrefractory particulate matter simultaneously (Cross et al., 2010; Onasch et al., 2012; Corbin et al., 2014). SP-AMS was previously used to quantify $\mathrm{rBC}$ mass concentration, mixing state and chemical composition in urban environment and biomass burning influenced air (Lee et al., 2015a, b; Willis et al., 2016).

As a highly complementary instrument, single particle aerosol mass spectrometer (SPAMS, not to be confused with the SP-AMS instrument mentioned above) can detect the chemical properties of $\mathrm{BC}$ particles. Moffet and Prather (2009) observed a rapid coating process of organic carbon and sulfate on the $\mathrm{BC}$ core and assessed the related absorption enhancement during an air pollution episode over Mexico City. Healy et al. (2012b) found that the mass size distribution for BC-containing particles was bimodal at an urban background site in Paris. The smaller mode was attributed to local emission, mostly externally mixed BC particles, while the larger mode was dominated by aged particles associated with continental transport events. Zhang et al. (2014) found that an active photochemical formation of secondary organic aerosol (SOA) led to a distinct diurnal pattern of mixing state of BC with SOA in the condensation mode, while the photochemical aging had limited or negligible influence on the mixing state and growth of $\mathrm{BC}$ in the droplet mode. The size ranges of condensation mode (vacuum aerodynamic diameter $\left(D_{\text {va }}\right)=\sim 100-300 \mathrm{~nm}$ ) and droplet mode $\left(D_{\mathrm{va}}=\sim 300-1000 \mathrm{~nm}\right)$ were defined by John et al. (1990) and Seinfeld and Pandis (2012).

Depending on the experimental method, different terms are used in the literature for the most refractory and lightabsorbing components of carbonaceous aerosols: black carbon (BC), refractory black carbon ( $\mathrm{rBC}$ ) and elemental carbon (EC). The definitions of $\mathrm{BC}, \mathrm{rBC}$ and $\mathrm{EC}$ have been discussed in details elsewhere (Bond and Bergstrom, 2006; Almeida et al., 2013; Petzold et al., 2013). In this paper, we use $\mathrm{rBC}$ and BC to illustrate the SP2 and SPAMS data, respectively.

All of the studies mentioned above relied on either an SP2 instrument or a single particle aerosol mass spectrometer to characterize $\mathrm{BC}$ particles, but not both. Combining these two methods would provide the chemical and physical prosperities of individual BC particles simultaneously and greatly enhance our understanding of their sources and evolution processes. Furthermore, most previous SP2 studies focused on the $\mathrm{rBC}$ particles during relatively clean days. Quantitative analysis on the mixing state of $\mathrm{BC}$ particles during heavy pollution episodes is still lacking. In this study, we deployed two complementary techniques, with single particle resolution and high time resolution, to detect the evolution of the urban BC aerosols in Shanghai during an extreme pollution period. We used an SP2 instrument to measure the mass and size distribution, and the mixing state of individual $\mathrm{rBC}$ particles. A SPAMS instrument was used in parallel to record chemical characteristics and mixing state of individual BC particles.

\section{Experimental}

\subsection{Single particle soot photometer}

\subsubsection{Description}

The number and mass size distribution, as well as the mixing state of individual $\mathrm{rBC}$ particles were characterized using a single particle soot photometer (SP2, Droplet Measurement Technologies, Inc., Boulder, CO) (Stephens et al., 2003; 
Baumgardner et al., 2004). In brief, SP2 detects incandescence and scattering signals of rBC-containing particles induced by a $1064 \mathrm{~nm}$ Nd:YAG intra-cavity laser. The mass of $\mathrm{rBC}$ is proportional to the intensity of the laser-induced incandescence signal. Any measured particle with a detectable incandescence signal is treated as an $\mathrm{rBC}$ particle; whereas a particle that only exhibits scattering signal is considered as a non-rBC particle. The total $\mathrm{rBC}$ mass loading is reported as the sum of all detected single rBC masses. The SP2 instrument samples at a low flow rate $\left(30 \mathrm{~cm}^{3} \mathrm{~min}^{-1}\right)$ in order to avoid multiple particles crossing the laser at the same time. We only saved data for every 50th particle in order to extend the sampling time without generating excessively large data sets.

\subsubsection{Calibration and detection efficiency}

The SP2 incandescence signal was calibrated using Aquadag $^{\circledR}$ black carbon particles (Aqueous Deflocculated Acheson Graphite, manufactured by Acheson Inc., USA). The Aquadag ${ }^{\circledR}$ black carbon particles were selected by mobility diameter using a differential mobility analyzer (DMA) and the corresponding particle masses were calculated using the effective density data provided in Gysel et al. (2011) (Fig. S1 in the Supplement). The scattering signal was calibrated using mono-disperse polystyrene latex spheres (Nanosphere Size Standards, Duke Scientific Corp., Palo Alto, CA, USA) with known diameters $(80-350 \mathrm{~nm})$. More details about the SP2 calibration can be found in Gysel et al. (2011), Baumgardner et al. (2012) and Laborde et al. (2012). A diagram of the calibration system is shown in the Supplement (Fig. S2).

The detection efficiency was measured using Aquadag ${ }^{\circledR}$ black carbon particles, and the results are shown in Fig. S3. The details of the measurement method were described in Schwarz et al. (2010). SP2 detection efficiency was nearly unity for larger $\mathrm{rBC}$ particles. The minimum $\mathrm{rBC}$ mass that could be observed with near-unity detection efficiency was $\sim 0.7 \mathrm{fg} \mathrm{rBC}$, corresponding to $90 \mathrm{~nm}$ mass-equivalent diameter; the detection efficiency declined rapidly at lower sizes (Fig. S3). The total ambient mass concentrations of $\mathrm{rBC}$ were underestimated because of the low detection efficiency of the smaller rBC particles, likely by $\sim 20 \%$ (Schwarz et al., 2006; McMeeking et al., 2010). During the calibration and sampling time, the SP2 was operated at a stable temperature of $20^{\circ}$ and pressure of $\sim 1013 \mathrm{hPa}$. The SP2 laser current was around $1750 \mathrm{~mA}$ through the whole experiment.

\subsubsection{Data analysis}

The rBC mass in each individual particle was determined from the peak intensity of the incandescence signal according to the Aquadag ${ }^{\circledR}$ black carbon calibration (Sect. 2.1.2). The conversion from the mass to the effective $\mathrm{rBC}$ core diameter requires making assumptions about the morphol- ogy and effective density of the $\mathrm{rBC}$ cores in the particles. Zhang et al. (2015) recently found the ambient rBC cores had an average shape factor of 1.2 and an average density of $1.2 \mathrm{~g} \mathrm{~cm}^{-3}$, suggesting a near- spherical shape with an internal void of $30 \%$ by volume. With the aging process, Zhang et al. (2015) observed that the effective density of BC core increased and the cores transformed to a more compact shape. In this study, we focused on the aged BC-containing particles. Therefore, a density of $1.8 \mathrm{~g} \mathrm{~cm}^{-3}$ was used to convert the ambient $\mathrm{rBC}$ mass to the mass equivalent diameter. This value was also recommended in many previous studies (Bond and Bergstrom, 2006; Moteki and Kondo, 2010; Moteki et al., 2010; McMeeking et al., 2011).

In addition to the $\mathrm{rBC}$ mass, the measurement of the scattering signal of an $\mathrm{rBC}$-containing particle allows for the determination of its scattering cross section. However, the scattering properties of externally and internally mixed $\mathrm{rBC}$ particles, as detected by the SP2, may be distorted, because the mass of each particle is reduced by the laser heating. Thus, scattered light from a sampled $\mathrm{rBC}$ particle does not yield a full Gaussian waveform. The Gaussian scattering function was reconstructed from the leading edge of the scattering signal (before the particle is perturbed by the laser), which was measured with a two-element avalanche photodiode (APD). This method allows SP2 to determine the scattering properties of individual $\mathrm{rBC}$ particles as well as the $\mathrm{rBC}$ mass and to distinguish the mixing state of a single $\mathrm{rBC}$ particle (so called LEO-fit method; Gao et al., 2007). The optical diameter of an $\mathrm{rBC}$ particle or the coated $\mathrm{rBC}$ size $\left(D_{\mathrm{p}}\right)$ was derived by inputting the LEO fitted scattering signal and rBC core size $\left(D_{\mathrm{c}}\right)$ into Mie calculations with a core refractive index $m=2.26-1.26 i$ (Moteki et al., 2010; Liu et al., 2014; Laborde et al., 2013) and a coating refractive index $m=1.5+0 i$ (Laborde et al., 2013). The absolute coating thickness (ACT) of an $\mathrm{rBC}$ particle was calculated as $\left(D_{\mathrm{p}}-D_{\mathrm{c}}\right) / 2$, based on the assumption of a concentric coreshell morphology. However, $\mathrm{rBC}$ aging processes in the real atmosphere may result in aerosols with particles that deviate from the core-shell morphology (Matsui et al., 2013). For example, when a small $\mathrm{rBC}$ particle coagulates with a relatively large $\mathrm{rBC}$-free particle, the small $\mathrm{rBC}$ particle may stay at the surface and lead to an effective negative coating thickness if determined by the methods used here. In this study, the negative coating thickness was observed for less than $2 \%$ of all rBC-containing particles; we did not take those particles into account when we calculated the average ACT. More details of data analysis and uncertainties are discussed in the Supplement, as well as in Liu et al. (2014) and Laborde et al. (2013).

\subsection{Single particle aerosol mass spectrometer}

A SPAMS instrument (Hexin Analytical Instrument Co., Ltd., Guangdong, China) was deployed simultaneously with SP2 to detect chemical composition of BC-containing particles. The technical details of SPAMS have been described 
elsewhere (Li et al., 2011). Briefly, aerosols in the size range of $0.2-2.0 \mu \mathrm{m}$ are introduced into the focus lens through a $0.1 \mathrm{~mm}$ critical orifice at a flow of $80 \mathrm{~mL} \mathrm{~min}^{-1}$ due to the pressure drop from $\sim 760$ to $\sim 2.2$ Torr. Then particles are accelerated to a terminal size-dependent aerodynamic velocity, which is measured by two orthogonally oriented continuous lasers $(532 \mathrm{~nm})$ separated by a fixed $6.0 \mathrm{~cm}$ distance. A pulsed desorption/ionization laser (Q-switched Nd:YAG laser, $266 \mathrm{~nm}$ ) is triggered when a particle arrives at the ion source region. Both positive and negative ions are detected simultaneously by the time-of-flight mass spectrometer. In this work, the power of the desorption/ionization laser was kept at $\sim 0.6 \mathrm{~mJ}$ per pulse. The particle size was calculated from the measured speed using a calibration curve generated for mono-disperse polystyrene latex spheres (Nanosphere Size Standards, Duke Scientific Corp., Palo Alto, CA, USA) with known diameters $(0.22-2.00 \mu \mathrm{m})$.

All single particle mass spectra were converted into a list of peaks at each $m / z$ using TSI MS-Analyze software with a minimum signal threshold of 30 arbitrary units above the baseline. The resulting peak lists were then imported into YAADA (www.yaada.org), a software toolkit in Matlab (version R2012b) for further analysis of particle sizes and chemical components. A total of 385683 particles were chemically analyzed with both positive and negative ion spectra, accounting for about $56 \%$ of all sized particles. Based on the similarities of the mass-to-charge ratio and peak intensity, particles were clustered by using the ART-2a (adaptive resonance theory) method (Song et al., 1999) with a vigilance factor of 0.85 , a learning rate of 0.05 and 20 iterations. Then BC-containing particles, with $D_{\mathrm{va}}$ in the size range of 200-1200 nm, were chosen from the clusters, since this size range was consistent with the dominant fraction of BCcontaining mass in the atmosphere (Zhang et al., 2014; Healy et al., 2012b). Finally, a total of 86057 BC-containing particles were grouped into six general particle types according to mass spectral patterns.

\subsection{Monitor for Aerosols and Gases (MARGA)}

A MARGA instrument (ADI 2080, Applikon Analytical B. B. Corp., Netherlands) was used to measure water-soluble inorganic ions in particles. The details of MARGA have been described previously (Jongejan et al., 1995; Du et al., 2011). Briefly, air to be analyzed enters into sample boxes via a $\mathrm{PM}_{1}$ cyclone. The air flow is maintained at $1 \mathrm{~m}^{3} \mathrm{~h}^{-1}$ by a mass flow controlled air pump. In the sample box, water-soluble gases ( $\mathrm{HCl}, \mathrm{HONO}, \mathrm{SO}_{2}, \mathrm{HNO}_{3}, \mathrm{NH}_{3}$ ) are completely absorbed in a dilute solution of hydrogen peroxide by using a wet rotating denuder (WRD). Aerosols pass through the WRD and are subsequently collected in a steam-jet aerosol collector (SJAC). The two liquid samples with absorbed gases and particles are accumulated in syringes in the analytical box. After filling the syringes for 1 hour, the samples are then injected into an ion chromatograph (IC). The IC is continuously controlled by an internal calibration method using a standard $\mathrm{LiBr}$ solution. In this study, the water-soluble inorganic ions (i.e., $\mathrm{K}^{+}, \mathrm{SO}_{4}^{2-}, \mathrm{NO}_{3}^{-}$) in bulk particles were analyzed.

\subsection{Sampling period and site}

The sampling lasted for almost 5 days, from 5 to 10 December 2013. The instruments were operated in the building of the Department of Environmental Science and Engineering, Fudan University (FDU, $31^{\circ} 14^{\prime} \mathrm{N}, 121^{\circ} 29^{\prime} \mathrm{E}$ ) in urban Shanghai, close to both residential and traffic emissions sources. Aerosols were sampled with a $\mathrm{PM}_{2.5}$ cyclone positioned $2 \mathrm{~m}$ above the roof of the building and transferred to the instruments through a $6 \mathrm{~m}$ long stainless steel pipe ( $45 \mathrm{~mm}$ inner diameter). A pump was used to pull air through the sampling system at $30 \mathrm{~L} \mathrm{~min}^{-1}$, minimizing the particle residence time in the sampling line. Aerosols were dried by diffusion drying tubes before they reached the SP2 and SPAMS inlets, which were connected in parallel. The measurement system is presented in Fig. S2. Because of the extremely high particle mass loading, the inlets of SP2 and SPAMS were clogged two times during the sampling period.

\section{Result and discussion}

\subsection{Overview of the meteorology and air quality}

Temporal variations of measured relative humidity, temperature, $\mathrm{CO}, \mathrm{O}_{3}, \mathrm{NO}, \mathrm{NO}_{2}, \mathrm{SO}_{2}, \mathrm{PM}_{2.5}$ and $\mathrm{PM}_{10}$ in Shanghai from 12:00 LT on 5 December to 14:00 LT on 10 December are shown in Fig. 1. The meteorology and air quality information were provided by the Shanghai Environmental Monitoring Center, Hongkou Station (http://www.semc.com.cn/ aqi/home/Index.aspx). The station is $3.3 \mathrm{~km}$ north from the sampling site. The temperature and relative humidity varied between 2 and $19^{\circ}$ and 30 and $100 \%$, with an average of $19^{\circ}$ and $73 \%$, respectively, during the study. The $\mathrm{O}_{3}$ concentration was relatively low from 18:00 LT on 5 December to 08:00 LT on 7 December. The CO concentration showed two peaks during this period, and its peak value reached $4.1 \mathrm{mg} \mathrm{m}^{-3}$ at 14:00 LT on 6 December. The $\mathrm{NO}_{2}$ concentration increased quickly at the beginning, reached $202.5 \mu \mathrm{g} \mathrm{m}^{-3}$ at 21:00 LT on 5 December, and then decreased slowly until 12:00 LT on 7 December. After 12:00 LT on 7 December, the concentrations of $\mathrm{O}_{3}, \mathrm{CO}, \mathrm{NO}_{2}$ and $\mathrm{SO}_{2}$ fluctuated without an obvious pattern. The concentrations of $\mathrm{O}_{3}$ and $\mathrm{NO}_{2}$ showed the expected anti-correlation, because $\mathrm{NO}$ was oxidized to $\mathrm{NO}_{2}$ by $\mathrm{O}_{3}$. The $\mathrm{CO}$ concentration was found to correlate reasonably well with $\mathrm{rBC}$ mass concentration $\left(R^{2}=0.59\right.$, slope $\left.=0.33\right)$, as shown in Fig. S4.

The mass loading of $\mathrm{PM}_{2.5}$ was extremely high during this period. Its maximum value reached $636 \mu \mathrm{g} \mathrm{m}^{-3}$ at 12:00 LT on 6 December, which was a record-breaking hourly concentration for Shanghai. The daily average con- 


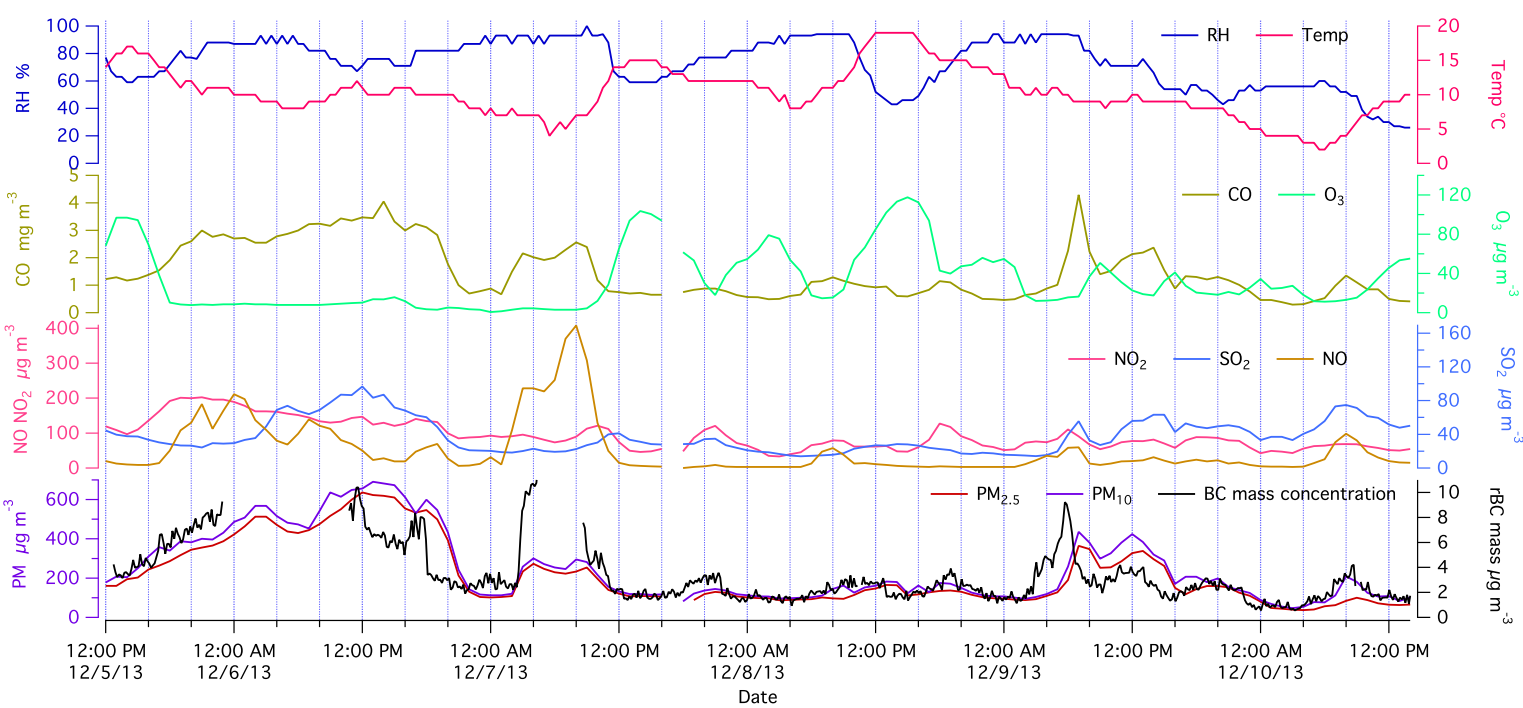

Figure 1. Temporal profiles of temperature and relative humidity with 30 min resolution, gaseous pollutants $\left(\mathrm{CO}, \mathrm{O}_{3}, \mathrm{SO} 2, \mathrm{NO}\right.$ and $\left.\mathrm{NO}{ }_{2}\right)$ with 60 min resolution, and $\mathrm{PM}_{2.5}$ and $\mathrm{PM}_{10}$ mass concentrations with 60 min resolution. The concentration of $\mathrm{rBC}$ mass (black trace in the bottom panel, 10 min resolution) was continuously measured by SP2.

centration was $221 \mu \mathrm{g} \mathrm{m}^{-3}$. Meanwhile, $\mathrm{PM}_{10}$ varied from 47 to $691 \mu \mathrm{g} \mathrm{m}^{-3}$, with an average of $252 \mu \mathrm{g} \mathrm{m}^{-3}$. Concentrations of $\mathrm{CO}, \mathrm{O}_{3}, \mathrm{NO}, \mathrm{NO}_{2}, \mathrm{SO}_{2}, \mathrm{PM}_{10}$ and $\mathrm{PM}_{2.5}$ during 5-10 December all exceeded the Chinese national ambient air quality standards.

\subsection{BC size distributions and concentration measurement by SP2}

We fitted a log-normal distribution to the rBC core number and mass size measurements during the entire sampling period, as shown in Fig. 2. The number size distribution spanned the range from $\sim 60$ to $\sim 400 \mathrm{~nm}$ and the peak was around $\sim 60 \mathrm{~nm}$. The measured number concentrations dropped below $60 \mathrm{~nm}$ because the SP2 detection efficiency greatly decreases (Sect. 2.1.2) below this particle size. Using the same method, Schwarz et al. (2008) also found that the peak concentration was around $60 \mathrm{~nm}$ in boundary layer. The $\mathrm{rBC}$ core mass size distribution had a peak around $200 \mathrm{~nm}$, and the majority of the rBC mass was distributed between 70 and $500 \mathrm{~nm}$.

As shown in Fig. 1, the rBC mass concentration varied from $0.6 \mu \mathrm{g} \mathrm{m}^{-3}$ at 00:02 LT on 10 December to $12.1 \mu \mathrm{g} \mathrm{m}^{-3}$ at 04:26 LT on 7 December, with an average of $3.2 \mu \mathrm{g} \mathrm{m}^{-3}$. The rBC mass concentration observed in Shanghai was similar to other cities in China, e.g., $\sim 4.1 \mu \mathrm{g} \mathrm{m}^{-3}$ in Shenzhen (Huang et al., 2012) and $\sim 3.3 \mu \mathrm{g} \mathrm{m}^{-3}$ in Kaiping (Huang et al., 2011). However, it was much higher than in other megacities around the world, e.g., $\sim 0.9 \mu \mathrm{g} \mathrm{m}^{-3}$ in Paris (Laborde et al., 2013) and $\sim 1.3 \mu \mathrm{g} \mathrm{m}^{-3}$ in London (Liu et al., 2014). All of the values quoted above were based on SP2 measurement so a direct comparison is possible. The rBC mass ac-

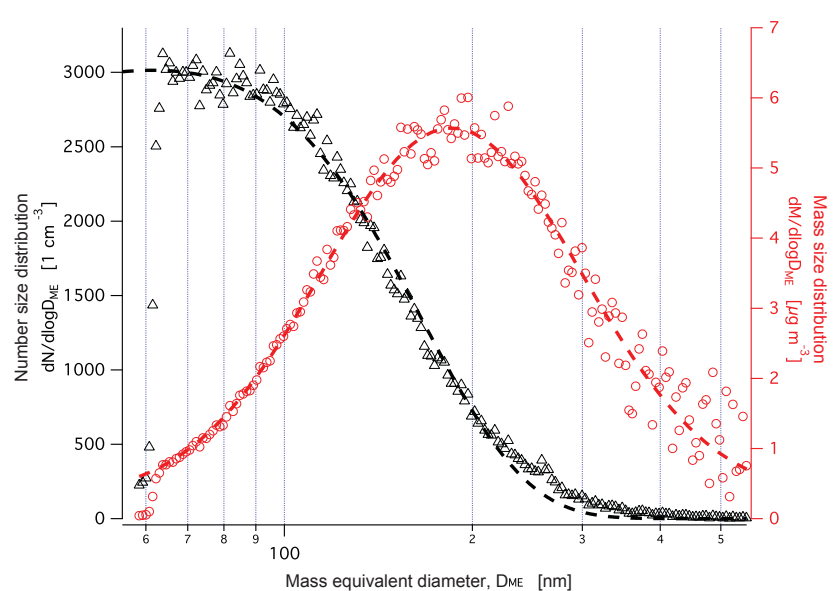

Figure 2. The measured rBC core mass size distribution and number size distribution are shown in open red circles and black triangles, respectively. The log-normal fits to the observed distributions are shown by the dashed lines.

counted for $1.45 \%$ of $\mathrm{PM}_{2.5}$ mass on average in our measurements.

\subsection{BC particles classification by SPAMS}

Classification of particles analyzed by the SPAMS can help elucidate the sources, degree of aging, and mixing state of $\mathrm{BC}$ particles. We classified BC-containing particles into six groups according to their mass spectral characteristics. The names of these groups and their number fractions are shown in Table 1. The average mass spectral patterns of each group are shown in Fig. S5. 
Table 1. Names, numbers and fractions of the six types of BC-containing particles detected by the SPAMS instrument.

\begin{tabular}{lrr}
\hline Group & Number of particles & Fraction of particles \\
\hline Pure BC & 535 & $0.62 \%$ \\
Biomass Burning BC-containing (BBBC) & 22007 & $25.57 \%$ \\
K-rich BC-containing (KBC) & 11343 & $13.18 \%$ \\
BC internally mixed with OC and ammonium nitrate $\left(\right.$ BCOC-NO $\left._{x}\right)$ & 33760 & $39.23 \%$ \\
BC internally mixed with OC and ammonium sulfate $\left({\left.\mathrm{BCOC}-\mathrm{SO}_{x}\right)}\right)$ & 15291 & $17.77 \%$ \\
Unidentified & 3121 & $3.63 \%$ \\
Total BC-containing & 86057 & $100 \%$ \\
\hline
\end{tabular}

Pure $\mathrm{BC}$ particles only presented strong signals for black carbon fragment ions $\left(\mathrm{C}_{n}^{-}\right.$and $\left.\mathrm{C}_{n}^{+}\right)$in both positive and negative ion mass spectra without any signal of secondary species like sulfate or nitrate, suggesting they were fresh BC particles that had not undergone any aging process.

Biomass burning $\mathrm{BC}$-containing (BBBC) particles were characterized by an intense $\mathrm{K}^{+}$signal for +39 (the charge and $m / z$ of the observed ion), $+113\left(\mathrm{~K}_{2} \mathrm{Cl}^{+}\right)$and +213 $\left(\mathrm{K}_{3} \mathrm{SO}_{4}^{+}\right)$in the positive ion mass spectra and a strong signal for $-26\left(\mathrm{CN}^{-}\right)$and $-42\left(\mathrm{CNO}^{-}\right)$in the negative ion mass spectra. A significant fragment of levoglucosan, -71 $\left(\mathrm{C}_{3} \mathrm{H}_{3} \mathrm{O}_{2}^{-}\right)$, was also observed. Typical black carbon fragments $\left(\mathrm{C}_{n}^{-}\right)$appeared in the negative ion mass spectra. A high signal at $-46\left(\mathrm{NO}_{2}^{-}\right),-62\left(\mathrm{NO}_{3}^{-}\right)$and a relatively low signal at $-97\left(\mathrm{HSO}_{4}^{-}\right)$were also observed, suggesting a significant accumulation of nitrate ions on $\mathrm{BC}$ particles throughout the air pollution period. The criteria for the identification of BBBC particles is discussed in the Supplement. Potassiumcontaining soot is a well-established tracer for biomass combustion (Andreae, 1983; Soto-García et al., 2011). Watersoluble $\mathrm{K}^{+}$in ambient particles measured by an online MARGA method correlated reasonably well with the BBBC particles number $\left(R^{2}=0.64\right)$, as shown in Fig. S6. Particles with similar mass spectral patterns were previously observed in several urban field studies and assigned to biomass burning sources (Moffet et al., 2008; Healy et al., 2012b; Bi et al., 2011).

BC internally mixed with organic carbon and ammo-

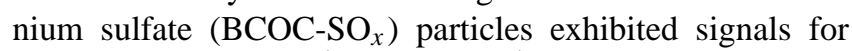
ammonium $+17\left(\mathrm{NH}_{3}^{+}\right),+18\left(\mathrm{NH}_{4}^{+}\right)$, organic carbon +37 $\left(\mathrm{C}_{3} \mathrm{H}^{+}\right),+43\left(\mathrm{CH}_{3} \mathrm{CO}^{+}\right),+50\left(\mathrm{C}_{4} \mathrm{H}_{2}^{+}\right),+51\left(\mathrm{C}_{4} \mathrm{H}_{3}^{+}\right),+61$ $\left(\mathrm{CH}_{3} \mathrm{C}(\mathrm{OH})=\mathrm{OH}^{+}\right),+62\left(\left(\mathrm{CH}_{3}\right)_{2} \mathrm{NHOH}^{+}\right)$, and a small signal for sodium $+23\left(\mathrm{Na}^{+}\right)$in the positive ion mass spectra, along with black carbon fragment ions $\left(\mathrm{C}_{n}^{+}\right)$. There was a high signal for sulfate $-97\left(\mathrm{HSO}_{4}^{-}\right)$and a relatively low signal for nitrate $-46\left(\mathrm{NO}_{3}^{-}\right),-62\left(\mathrm{NO}_{3}^{-}\right)$in the negative ion spectra. $\mathrm{BC}$ internally mixed with organic carbon and ammonium nitrate $\left(\mathrm{BCOC}-\mathrm{NO}_{x}\right)$ particles are characterized by very similar positive ion mass spectra to $\mathrm{BCOC}-\mathrm{SO}_{x}$, but exhibit lower signals for sulfate and higher signals for nitrate in the negative ion spectra, i.e., $-46\left(\mathrm{NO}_{3}^{-}\right),-62\left(\mathrm{NO}_{3}^{-}\right)$. $\mathrm{BC}$ particles with various intensities for organic carbon, ni- trate and sulfate were commonly detected in urban ATOFMS field studies (Moffet et al., 2008; Ault et al., 2009; Dall'Osto and Harrison, 2006) and were assigned to traffic emissions (Healy et al., 2012b).

K-rich BC-containing (KBC) particles exhibited strong signals for black carbon fraction in both positive and negative ion mass spectra. This class also had signals for potassium $+39\left(\mathrm{~K}^{+}\right)$, sodium $+23\left(\mathrm{Na}^{+}\right)$and ammonium $+17\left(\mathrm{NH}_{3}^{+}\right)$, $+18\left(\mathrm{NH}_{4}^{+}\right)$in positive ion mass spectra and nitrate -46 $\left(\mathrm{NO}_{2}^{-}\right),-62\left(\mathrm{NO}_{3}^{-}\right)$, and sulfate $-97\left(\mathrm{HSO}_{4}^{-}\right)$in the negative ion mass spectra. This class was detected from diesel vehicle emissions in a previous study by Li et al. (2013). The KBC exhibited pronounced diurnal variation, with two major peaks during early morning (04:00-07:00 LT) and night hours (20:00-22:00 LT) (Fig. S7). Shanghai municipal government regulates that the heavily loaded diesel trucks cannot go into the downtown area from 07:00 to 20:00 LT. The diurnal variation of $\mathrm{KBC}$ is consistent with the traffic flow of diesel trucks based on our results.

$\mathrm{NO}_{x}$ can be used as a tracer of local traffic emissions in urban areas. In this study, the $\mathrm{NO}_{x}$ concentrations agreed well with the sum of $\mathrm{KBC}, \mathrm{BCOC}-\mathrm{NO}_{x}$ and $\mathrm{BCOC}-\mathrm{SO}_{x}$ particles numbers $\left(R^{2}=0.65\right)$ (Fig. S8). Based on the above analysis, we believed that the BBBC came from biomass burning, $\mathrm{KBC}$, and $\mathrm{BCOC}-\mathrm{NO}_{x}$ and $\mathrm{BCOC}-\mathrm{SO}_{x}$ came from traffic emissions.

We should note that SPAMS preferentially detected internally mixed BC particles, and had reduced detection efficiency for pure BC particles. The particles detected and chemically analyzed by SPAMS range from 200 to $2000 \mathrm{~nm}$ in size, and the detection efficiency decreases rapidly below $400 \mathrm{~nm}$ and above $1200 \mathrm{~nm}$ (Li et al., 2011). The majority of the pure BC particles diameter are smaller than $200 \mathrm{~nm}$ in diameter (Kondo et al., 2006), and therefore, they are missed by SPAMS. 


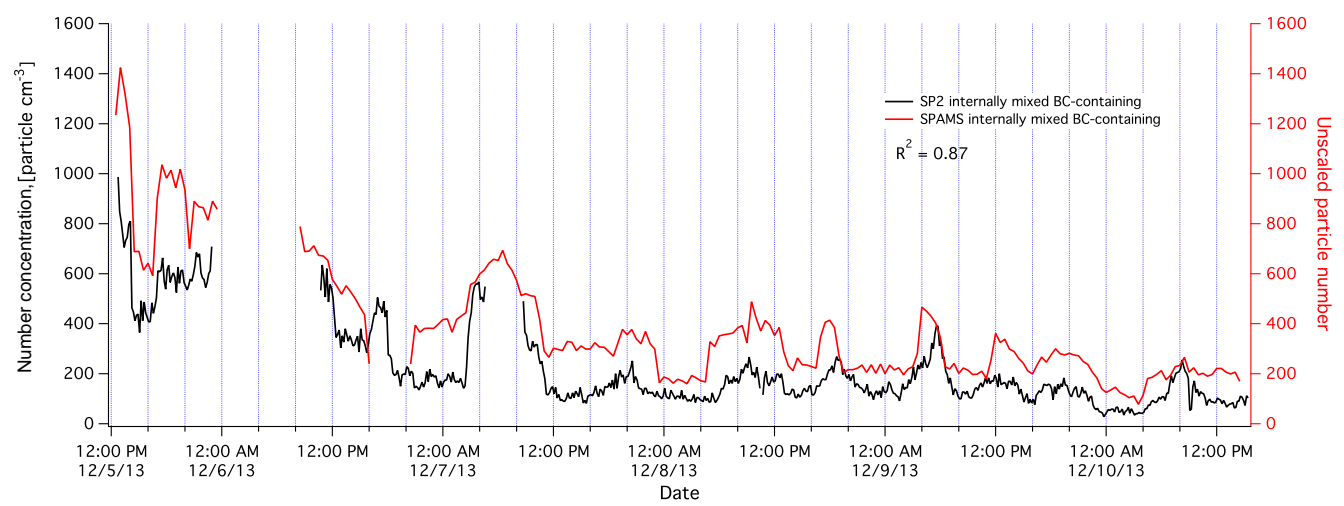

Figure 3. Comparison of the SPMAS-detected internally mixed BC-containing particles and SP2-detected internally mixed rBC-containing particles.

\subsection{Mixing state and size distribution of internally mixed BC particles}

\subsubsection{Temporal variations of internally mixed BC particles}

A comparison of the internally mixed $\mathrm{BC}$ particles number concentration between SP2 and SPAMS is given in Fig. 3. The agreement observed is reasonably good $\left(R^{2}=0.87\right)$ considering the combined experimental uncertainties of the methods and the different cut-off diameters of SP2 $\left(D_{\mathrm{p}}>\right.$ $170 \mathrm{~nm})$ and SPAMS $\left(200 \mathrm{~nm}<D_{\mathrm{va}}<1200 \mathrm{~nm}\right)$. Detected by SP2, the internally mixed rBC particles accounted for approximately $70 \%$ number fraction of BC-containing particles during the whole period. Moteki et al. (2007) also found the internally mixed rBC particles accounted for $63 \%$ number fraction of BC-containing particles in the aged urban plume. The high correlation coefficient indicates that we can use the two complementary techniques to analyze the mixing state and chemical composition of internally mixed BC particles with single particle resolution at the same time (although not for the same particle since both methods are destructive).

The temporal variation of number size distribution and particle types changed rapidly and intricately, as shown in Fig. 4. From 12:00 LT on 5 December to 00:00 LT on 7 December, the $\mathrm{PM}_{2.5}$ and $\mathrm{rBC}$ mass increased slowly to an extremely polluted state. The number fraction of BBBC particles also increased during this period (Fig. 4b) and $D_{\mathrm{p}}$ of rBC showed two distinct modes (Fig. 4a). Then, the BCcontaining particles number increased rapidly at 02:00 LT on 7 December. Presumably, boundary layer compression during the night led the fast change of $\mathrm{BC}$-containing particles. After that, the number concentration of BC-containing particles exhibited diurnal variation, with two major peaks at the rush hours, i.e., from 08:00 to 12:00 LT or from 16:00 to 20:00 LT.
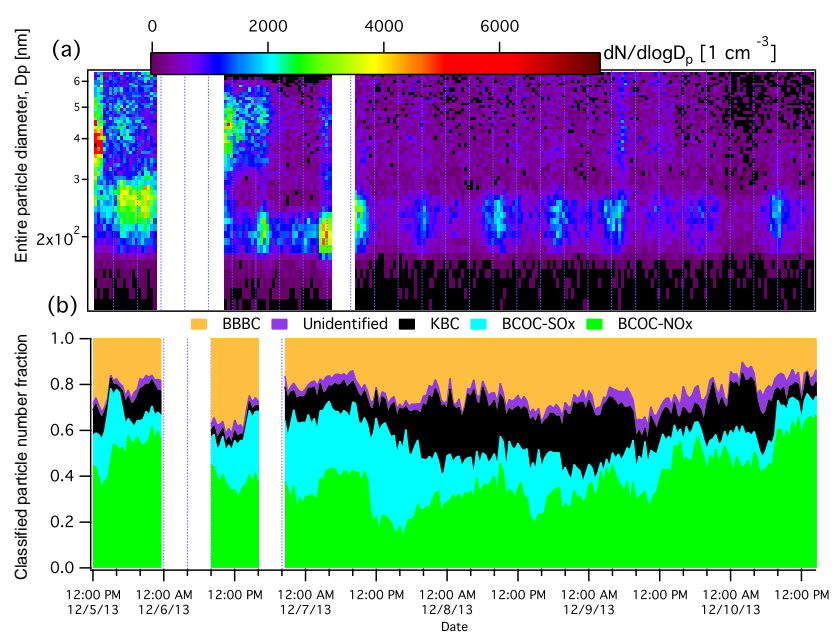

Figure 4. (a) Temporal variations of number and size distributions for rBC-containing particles detected by SP2 with 30 min resolution. (b) Temporal variation of number fractions of different BCcontaining particle types with $10 \mathrm{~min}$ time resolution (detected by SPAMS).

\subsubsection{Size distribution and source apportionments of internally mixed BC particles}

Figure $5 \mathrm{a}$ shows the entire diameter $\left(D_{\mathrm{p}}\right)$ number size distribution histogram of internally mixed $\mathrm{rBC}$ particles detected by SP2 during the entire sampling period. The BC-containing particles were detected in both the condensation and droplet modes in this study. Since the two modes are overlapped, it is possible that some of the particles in the droplet mode are from the tail of condensation mode. Here, we used the minimum value between the two peaks in Fig. 5a (black line) and its corresponding $D_{\mathrm{p}}(320 \mathrm{~nm})$ as the separation of the condensation mode and droplet mode. We added this separation line in Fig. 5c to separate the condensation mode particles (left side) and the droplet mode particles (right side). The condensation mode peak was centered around $\sim 230 \mathrm{~nm}$ 

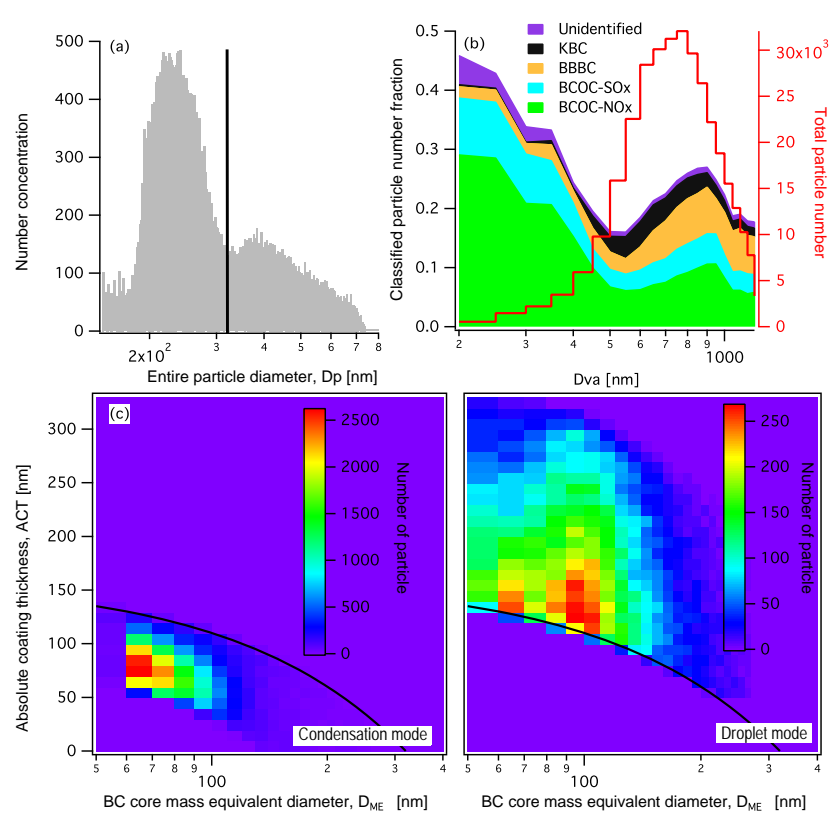

Figure 5. (a) $D_{\mathrm{p}}$ number size distribution histogram for the SP2detected rBC-containing particles. (b) $D_{\mathrm{va}}$ number fraction distribution of SPAMS-detected BC-containing particles color-coded by the particle type. (c) $D_{\mathrm{c}}$ and ACT with number size distribution in the condensation and droplet modes.

and droplet mode peak was centered around $\sim 380 \mathrm{~nm}$. The presence of condensation mode $\left(D_{\mathrm{va}}=\sim 200-500 \mathrm{~nm}\right)$ and droplet mode $\left(D_{\mathrm{va}}=\sim 550-1200 \mathrm{~nm}\right)$ was confirmed by the SPAMS data (Fig. 5b). Here the SPAMS size distribution was based on the number fraction of BC-containing particles in all detected particles. Similar particle size distributions were also found in other studies in China (Huang and Yu, 2008; Zhang et al., 2014).

The specific composition in condensation and droplet modes were quite different (Fig. 5b). BBBC particles exhibited a higher number fraction in the droplet mode than in the condensation mode. Ammonium nitrate can condense on particle surfaces during atmospheric transport if sulfate is fully neutralized and excess ammonia is available (Riemer et al., 2004). The sulfate condensation on BC surfaces occurs soon after the $\mathrm{BC}$ emission, while ammonium nitrate condensation occurs over longer timescales during transport (Healy et al., 2012a). In this work, most KBC and BBBC particles and all the BCOC- $\mathrm{NO}_{x}$ particles showed stronger $\mathrm{NO}_{3}^{-}$signals than $\mathrm{SO}_{4}^{-}$signals (as shown in Fig. S5), suggesting that most $\mathrm{BC}$-containing were deeply aged. Based on the particle classification and source apportionment analysis, the internally mixed BC particles from traffic emissions accounted for almost all of the particles observed in the condensation mode. However, the particle sources in the droplet mode were more diverse, including traffic emissions and biomass burning.

Previous studies revealed that different sources emit different core diameters for $\mathrm{rBC}$-containing particles (Liu et al., 2014; Takahama et al., 2014; Reddington et al., 2013; Schwarz et al., 2008) and the aging processes affect the coating thickness (Laborde et al., 2013; Liu et al., 2014). We identified the sources and estimated aging process of rBCcontaining particles by using 2-D image plot "fingerprint" of $D_{\mathrm{c}}$ and absolute coating thickness (ACT) information. Figure $5 \mathrm{c}$ shows the dependence of ACT on $D_{\mathrm{c}}$, weighed by the number concentration. In the condensation mode, the particles were characterized by small $D_{\mathrm{c}}$ values $(\sim 60$ $80 \mathrm{~nm})$ with thin ACT $(\sim 50-130 \mathrm{~nm})$. In combination with the SPAMS information, these particles with small $D_{\mathrm{c}}$ and thin ACT should be mainly from the traffic sources (Fig. 5b).

However, the droplet mode was very different from the condensation mode and showed a diversity of sources. In the droplet mode, the "fingerprint" showed two peaks in the size distribution. The first peak had small $D_{\text {c }}$ values $(\sim 60$ $80 \mathrm{~nm})$ and thick ACT $(\sim 130-300 \mathrm{~nm})$. We assume that the rBC-containing particles in the first peak were from traffic emissions. In previous studies, the particles associated with traffic emissions had small core sizes and thin coating thickness (Laborde et al., 2013; Liu et al., 2014). However, in this study, we found that the rBC-containing particles from traffic could be highly-aged, resulting in a much thicker coating than previously observed. This could be because polluted air masses promote faster $\mathrm{rBC}$ aging processes (Matsui et al., 2013). The second peak showed larger $D_{\mathrm{c}}(\sim 80-130 \mathrm{~nm})$ and thick ACT $(\sim 110-300 \mathrm{~nm})$. These particles were presumably from biomass burning. It has been reported using SP2 measurements that fresh biomass burning rBC particles are thickly coated (Schwarz et al., 2008; Sahu et al., 2012; Liu et al., 2014).

Since there was no clear-cut separation between traffic emissions and biomass burning rBC-containing particles in the droplet mode, it was hard to distinguish them when we just used the core and shell information from SP2 (Liu et al., 2014). We selected SP2-detected particles with larger core sizes $(80-130 \mathrm{~nm})$ and thicker coating $(120-300 \mathrm{~nm})$ and compared with the biomass burning particles number concentration from SPAMS, as shown in Fig. S9. The good correlation $\left(R^{2}=0.71\right)$ verified the conclusion that the rBCcontaining particles with larger cores and thicker coating were from biomass burning. Even though these larger rBCcontaining particles only accounted for less than $20 \%$ number fraction, they are likely to be more hygroscopic (Liu et al., 2013; Wang et al., 2014) and be scavenged by wet deposition (Moteki et al., 2012). Such particles will have greater potential to enhance the semi-direct effect (Koch and Del Genio, 2010) through interaction with cloud processes.

The diversity of sources of the droplet mode BCcontaining particles was also detected in SPAMS, as we discussed before. SPAMS data showed that the internally mixed $\mathrm{BC}$ particles from traffic emissions were more abundant in the droplet mode than those from biomass burning (Fig. 5b). However, the SP2 data showed that particles with a small core and thick ACT (major traffic emission) were less abun- 


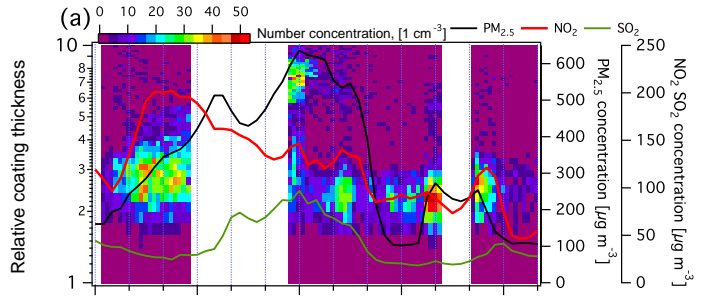

(b)

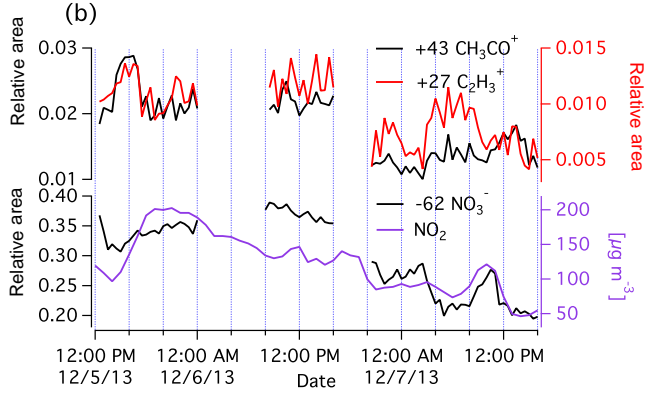

Figure 6. (a) Temporal variation of the relative coating thickness distribution of traffic-emitted $\mathrm{rBC}$-containing particles (SP2) with resolutions of $0.2 \mathrm{RCT}$ and $30 \mathrm{~min}$ and the temporal profile of $\mathrm{NO}_{2}$ and $\mathrm{PM}_{2.5}$ concentrations with $60 \mathrm{~min}$ resolution. (b) Temporal variation of relative peak areas of $+27\left(\mathrm{C}_{2} \mathrm{H}_{3}^{+}\right),+43$ $\left(\mathrm{CH}_{3} \mathrm{CO}^{+}\right)$and $-62\left(\mathrm{NO}_{3}^{-}\right)$of traffic-emitted $\mathrm{BC}$-containing particles (SPAMS) and $\mathrm{NO}_{2}$ concentration with 30 min resolution.

dant than particles with a larger core with thick ACT (major biomass burning) (Fig. 5c). As we discussed in Sect. 2.1.2, rBC-containing particle with smaller cores are not efficiently detected by SP2, which may result in an underestimation of the fraction of traffic emission of $\mathrm{rBC}$-containing particles in the droplet mode.

The aging of traffic-emitted $\mathrm{rBC}$-containing particles during the heavy air pollution episode (12:00 LT, 5 December 2013-12:00 LT, 7 December 2013) was elucidated using the temporal variation of relative coating thickness (RCT, entire particle diameter $/ \mathrm{rBC}$ core diameter, $\left.D_{\mathrm{p}} / D_{\mathrm{c}}\right)$ of $\mathrm{rBC}$ containing particles $\left(D_{\mathrm{c}}=60-80 \mathrm{~nm}\right)$, as shown in Fig. 6a. Note that we could only obtain optical sizing information from sufficiently coated particles because of the SP2 minimal detectable optical diameter of $\sim 170 \mathrm{~nm}$. From 16:00 to 22:00 LT on 5 December, the RCT of rBC-containing particles and $\mathrm{PM}_{2.5}$ concentration grew rapidly. Even though the SP2's inlet was blocked from 23:00 LT on 5 December to 10:00 LT on 6 December due to the extremely high PM mass loading, the data collected around that time suggest the rBC-containing particles growth was continuous until 13:00 LT on 6 December. The absolute coating growth rate was around $20 \mathrm{~nm} \mathrm{~h}^{-1}$ during this period (16:00 LT, 5 December-13:00 LT, 6 December).

Variations of the major chemical species in the vehicleemitted BC-containing particles (selected by SPAMS) were also analyzed. The relative peak areas of nitrate $-63\left(\mathrm{NO}_{3}^{-}\right)$and organic carbon (i.e., $+27\left(\mathrm{C}_{2} \mathrm{H}_{3}^{+}\right),+43$
$\left.\left(\mathrm{CH}_{3} \mathrm{CO}^{+}\right)\right)$showed a relatively high level during 16:00 LT on 5 December-13:00 LT on 6 December (Fig. 6b). Guo et al. (2014) observed that gaseous emissions of volatile organic compounds, nitrogen oxides from urban transportation and sulfur dioxide from region industry were responsible for large secondary particle matter formation in Beijing. Figure $\mathrm{S} 10$ shows the mass concentrations of $\mathrm{SO}_{2}, \mathrm{NO}_{2}$, the mass ratio of $\mathrm{NO}_{2} / \mathrm{SO}_{2}$, MARGA-measured mass concentrations of particulate sulfate and nitrate, and the mass ratio of $\mathrm{NO}_{3}^{-} / \mathrm{SO}_{4}^{2-}$ in $\mathrm{PM}_{1}$ during the whole sampling period. The average mass ratios of $\mathrm{NO}_{2} / \mathrm{SO}_{2}$ in gas phase and $\mathrm{NO}_{3}^{-} / \mathrm{SO}_{4}^{2-}$ in particles phase were 2.8 and 1.4 respectively. During the heavy air pollution episode (12:00 LT, 5 December 2013-13:00 LT, 6 December 2013), both $\mathrm{NO}_{2}$ and particulate nitrate increased dramatically along with the traffic emitted BC particle growth (as shown Fig. 6), while the $\mathrm{SO}_{2}$ and particulate sulfate had a slight increase and remained at a relatively lower level. Apparently, the gas to particle conversion of $\mathrm{NO}_{2}$ to nitrate played a more important role than the condensation of $\mathrm{SO}_{2}$ in the particle growth during this pollution episode. In the previous field studies (Huebert et al., 1988; Yao et al., 2002), the high mass ratio of $\mathrm{NO}_{3}^{-} / \mathrm{SO}_{4}^{2-}$ $(>1.0)$ was regarded as a sign of dominant traffic emission. Wang et al. (2015) found that the high mass ratio of $\mathrm{NO}_{2} / \mathrm{SO}_{2}$ resulting from traffic emissions was a major reason in triggering the heavy haze in Shanghai. In this work, the evaluation of $\mathrm{BC}$-containing particles also suggested that high concentrations of $\mathrm{NO}_{2}$ and possibly volatile organics and their transformations play a vital role for particle growth and the increase of PM loading in urban area especially during a heavy pollution episode. Reductions in the emissions of gaseous precursors are critical for remediation of the severe urban haze pollution in China.

\section{Conclusions}

In this study, we characterized BC-containing particles during a heavy air pollution episode in Shanghai. The rBC mass loading in Shanghai was similar to other cities in China but much higher than in other mega cities around the world, with an average of $3.2 \mu \mathrm{g} \mathrm{m}^{-3}$ and the peak value of $12.1 \mu \mathrm{g} \mathrm{m}^{-3}$ at 04:26 LT on 7 December 2013. The rBC mass accounted for $1.45 \%$ of $\mathrm{PM}_{2.5}$ mass on average. The number- and massweighted BC core size distributions were around $\sim 60-400$ and $70-500 \mathrm{~nm}$, with peaks around $\sim 60$ and $\sim 200 \mathrm{~nm}$, respectively.

Using SPAMS, we classified the BC-containing particles into six groups, according to their mass spectral patterns. The pure $\mathrm{BC}$ particles accounted for $0.62 \%$ number fraction of $\mathrm{BC}$-containing particles (although this number could be underestimated because of the low detection efficiency for pure $\mathrm{BC}$ in SPAMS). The BBBC particles from biomass burning accounted for $25.57 \%$. The KBC, BCOC-NO $x$ and BCOC- 
$\mathrm{SO}_{x}$ from traffic emissions accounted for $70.18 \%$. The remaining unidentified particles accounted for $3.63 \%$.

The size distribution of internally mixed $\mathrm{rBC}$ particles was bimodal. The condensation mode mainly consisted of traffic emissions, which had a small core $(\sim 60-80 \mathrm{~nm})$ with thin ACT $(\sim 50-130 \mathrm{~nm})$. The droplet mode included biomass burning and deeply aged traffic-emitted rBC-containing particles. The biomass burning particles had larger core sizes $(\sim 80-130 \mathrm{~nm})$ with thick ACT $(\sim 110-300 \mathrm{~nm})$ and the highly aged traffic emissions had small core sizes $(\sim 60$ $80 \mathrm{~nm})$ with thick ACT $(\sim 130-300 \mathrm{~nm})$. It is rare to see the traffic-emitted $\mathrm{rBC}$ growing so quickly to the droplet mode. The high concentration of $\mathrm{NO}_{2}$ and its rapid conversion to particulate nitrate accelerated the growth of $\mathrm{BC}$-containing particles and contributed to the high particle mass concentration during this heavy air pollution episode.

The quantitative number and mass information provided by SP2 supplemented the SPAMS chemical analysis in the entire experiment. The two complementary techniques can detect the physical and chemical properties of $\mathrm{BC}$ aerosol with single particle resolution. The combined use of SP2 and SPAMS have great promise for wider applications in future atmospheric measurements.

\section{The Supplement related to this article is available online at doi:10.5194/acp-16-5399-2016-supplement.}

Acknowledgements. This work was supported by the National Natural Science Foundation of China (91544224, 41275126), the Ministry of Science \& Technology of China (2012YQ220113-4), the Science \& Technology Commission of Shanghai Municipality (14XD1400600), the Ministry of Environmental Protection of China (201409008).

Edited by: H. Su

\section{References}

Adachi, K., Chung, S. H., and Buseck, P. R.: Shapes of soot aerosol particles and implications for their effects on climate, J. Geophys. Res.-Atmos., 115, D15206, doi:10.1029/2009JD012868, 2010.

Almeida, J., Schobesberger, S., Kurten, A., Ortega, I. K., Kupiainen-Maatta, O., Praplan, A. P., Adamov, A., Amorim, A., Bianchi, F., Breitenlechner, M., David, A., Dommen, J., Donahue, N. M., Downard, A., Dunne, E., Duplissy, J., Ehrhart, S., Flagan, R. C., Franchin, A., Guida, R., Hakala, J., Hansel, A., Heinritzi, M., Henschel, H., Jokinen, T., Junninen, H., Kajos, M., Kangasluoma, J., Keskinen, H., Kupc, A., Kurten, T., Kvashin, A. N., Laaksonen, A., Lehtipalo, K., Leiminger, M., Leppa, J., Loukonen, V., Makhmutov, V., Mathot, S., McGrath, M. J., Nieminen, T., Olenius, T., Onnela, A., Petaja, T., Riccobono, F., Riipinen, I., Rissanen, M., Rondo, L., Ruuskanen,
T., Santos, F. D., Sarnela, N., Schallhart, S., Schnitzhofer, R., Seinfeld, J. H., Simon, M., Sipila, M., Stozhkov, Y., Stratmann, F., Tome, A., Trostl, J., Tsagkogeorgas, G., Vaattovaara, P., Viisanen, Y., Virtanen, A., Vrtala, A., Wagner, P. E., Weingartner, E., Wex, H., Williamson, C., Wimmer, D., Ye, P. L., Yli-Juuti, T., Carslaw, K. S., Kulmala, M., Curtius, J., Baltensperger, U., Worsnop, D. R., Vehkamaki, H., and Kirkby, J.: Molecular understanding of sulphuric acid-amine particle nucleation in the atmosphere, Nature, 502, 359-363, doi:10.1038/nature12663, 2013.

Andreae, M. O.: Soot Carbon and Excess Fine Potassium: LongRange Transport of Combustion-Derived Aerosols, Science, 220, 1148-1151, doi:10.1126/science.220.4602.1148, 1983.

Ault, A. P., Moore, M. J., Furutani, H., and Prather, K. A.: Impact of Emissions from the Los Angeles Port Region on San Diego Air Quality during Regional Transport Events, Environ. Sci. Technol., 43, 3500-3506, doi:10.1021/es8018918, 2009.

Baumgardner, D., Kok, G., and Raga, G.: Warming of the Arctic lower stratosphere by light absorbing particles, Geophys. Res. Lett., 31, L06117, doi:10.1029/2003g1018883, 2004.

Baumgardner, D., Popovicheva, O., Allan, J., Bernardoni, V., Cao, J., Cavalli, F., Cozic, J., Diapouli, E., Eleftheriadis, K., Genberg, P. J., Gonzalez, C., Gysel, M., John, A., Kirchstetter, T. W., Kuhlbusch, T. A. J., Laborde, M., Lack, D., Müller, T., Niessner, R., Petzold, A., Piazzalunga, A., Putaud, J. P., Schwarz, J., Sheridan, P., Subramanian, R., Swietlicki, E., Valli, G., Vecchi, R., and Viana, M.: Soot reference materials for instrument calibration and intercomparisons: a workshop summary with recommendations, Atmos. Meas. Tech., 5, 1869-1887, doi:10.5194/amt-51869-2012, 2012.

Bi, X. H., Zhang, G. H., Li, L., Wang, X. M., Li, M., Sheng, G. Y., Fu, J. M., and Zhou, Z.: Mixing state of biomass burning particles by single particle aerosol mass spectrometer in the urban area of PRD, China, Atmos. Environ., 45, 3447-3453, doi:10.1016/j.atmosenv.2011.03.034, 2011.

Bond, T. C. and Bergstrom, R. W.: Light absorption by carbonaceous particles: An investigative review, Aerosol Sci. Tech., 40, 27-67, doi:10.1080/02786820500421521, 2006.

Bond, T. C., Doherty, S. J., Fahey, D. W., Forster, P. M., Berntsen, T., DeAngelo, B. J., Flanner, M. G., Ghan, S., Karcher, B., Koch, D., Kinne, S., Kondo, Y., Quinn, P. K., Sarofim, M. C., Schultz, M. G., Schulz, M., Venkataraman, C., Zhang, H., Zhang, S., Bellouin, N., Guttikunda, S. K., Hopke, P. K., Jacobson, M. Z., Kaiser, J. W., Klimont, Z., Lohmann, U., Schwarz, J. P., Shindell, D., Storelvmo, T., Warren, S. G., and Zender, C. S.: Bounding the role of black carbon in the climate system: A scientific assessment, J. Geophys. Res.-Atmos., 118, 5380-5552, doi:10.1002/jgrd.50171, 2013.

Cappa, C. D., Onasch, T. B., Massoli, P., Worsnop, D. R., Bates, T. S., Cross, E. S., Davidovits, P., Hakala, J., Hayden, K. L., Jobson, B. T., Kolesar, K. R., Lack, D. A., Lerner, B. M., Li, S. M., Mellon, D., Nuaaman, I., Olfert, J. S., Petaja, T., Quinn, P. K., Song, C., Subramanian, R., Williams, E. J., and Zaveri, R. A.: Radiative Absorption Enhancements Due to the Mixing State of Atmospheric Black Carbon, Science, 337, 1078-1081, doi:10.1126/science.1223447, 2012.

China, S., Mazzoleni, C., Gorkowski, K., Aiken, A. C., and Dubey, M. K.: Morphology and mixing state of individual freshly emitted wildfire carbonaceous particles, Nat. Commun., 4, 2122 , doi:10.1038/ncomms3122, 2013. 
Chung, S. H. and Seinfeld, J. H.: Global distribution and climate forcing of carbonaceous aerosols, J. Geophys. Res.-Atmos., 107, 4407, doi:10.1029/2001JD001397, 2002.

Corbin, J. C., Sierau, B., Gysel, M., Laborde, M., Keller, A., Kim, J., Petzold, A., Onasch, T. B., Lohmann, U., and Mensah, A. A.: Mass spectrometry of refractory black carbon particles from six sources: carbon-cluster and oxygenated ions, Atmos. Chem. Phys., 14, 2591-2603, doi:10.5194/acp-14-2591-2014, 2014.

Cross, E. S., Onasch, T. B., Ahern, A., Wrobel, W., Slowik, J. G., Olfert, J., Lack, D. A., Massoli, P., Cappa, C. D., Schwarz, J. P., Spackman, J. R., Fahey, D. W., Sedlacek, A., Trimborn, A., Jayne, J. T., Freedman, A., Williams, L. R., Ng, N. L., Mazzoleni, C., Dubey, M., Brem, B., Kok, G., Subramanian, R., Freitag, S., Clarke, A., Thornhill, D., Marr, L. C., Kolb, C. E., Worsnop, D. R., and Davidovits, P.: Soot Particle Studies Instrument InterComparisonProject Overview, Aerosol Sci. Tech., 44, 592-611, doi:10.1080/02786826.2010.482113, 2010.

Dall'Osto, M. and Harrison, R. M.: Chemical characterisation of single airborne particles in Athens (Greece) by ATOFMS, Atmos. Environ., 40, 7614-7631, doi:10.1016/j.atmosenv.2006.06.053, 2006.

Du, H., Kong, L., Cheng, T., Chen, J., Du, J., Li, L., Xia, X., Leng, C., and Huang, G.: Insights into summertime haze pollution events over Shanghai based on online water-soluble ionic composition of aerosols, Atmos. Environ., 45, 5131-5137, doi:10.1016/j.atmosenv.2011.06.027, 2011.

Gao, R., Schwarz, J., Kelly, K., Fahey, D., Watts, L., Thompson, T., Spackman, J., Slowik, J., Cross, E., and Han, J.-H.: A novel method for estimating light-scattering properties of soot aerosols using a modified single-particle soot photometer, Aerosol Sci. Tech., 41, 125-135, 2007.

Guo, S., Hu, M., Zamora, M. L., Peng, J., Shang, D., Zheng, J., Du, Z., Wu, Z., Shao, M., Zeng, L., Molina, M. J., and Zhang, R.: Elucidating severe urban haze formation in China, P. Natl. Acad. Sci., 111, 17373-17378, 2014.

Gysel, M., Laborde, M., Olfert, J. S., Subramanian, R., and Gröhn, A. J.: Effective density of Aquadag and fullerene soot black carbon reference materials used for SP2 calibration, Atmos. Meas. Tech., 4, 2851-2858, doi:10.5194/amt-4-2851-2011, 2011.

Healy, R. M., Chen, Y., Kourtchev, I., Kalberer, M., O’Shea, D., and Wenger, J. C.: Rapid Formation of Secondary Organic Aerosol from the Photolysis of 1-Nitronaphthalene: Role of Naphthoxy Radical Self-reaction, Environ. Sci. Technol., 46, 11813-11820, doi:10.1021/es302841j, 2012a.

Healy, R. M., Sciare, J., Poulain, L., Kamili, K., Merkel, M., Müller, T., Wiedensohler, A., Eckhardt, S., Stohl, A., Sarda-Estève, R., McGillicuddy, E., O'Connor, I. P., Sodeau, J. R., and Wenger, J. C.: Sources and mixing state of size-resolved elemental carbon particles in a European megacity: Paris, Atmos. Chem. Phys., 12, 1681-1700, doi:10.5194/acp-12-1681-2012, 2012b.

Huang, X.-F. and Yu, J. Z.: Size distributions of elemental carbon in the atmosphere of a coastal urban area in South China: characteristics, evolution processes, and implications for the mixing state, Atmos. Chem. Phys., 8, 5843-5853, doi:10.5194/acp-85843-2008, 2008.

Huang, X. F., Gao, R. S., Schwarz, J. P., He, L. Y., Fahey, D. W., Watts, L. A., McComiskey, A., Cooper, O. R., Sun, T. L., Zeng, L. W., Hu, M., and Zhang, Y. H.: Black carbon measurements in the Pearl River Delta region of China, J. Geophys. Res.-Atmos., 116, D12208, doi:10.1029/2010jd014933, 2011.

Huang, X. F., Sun, T. L., Zeng, L. W., Yu, G. H., and Luan, S. J.: Black carbon aerosol characterization in a coastal city in South China using a single particle soot photometer, Atmos. Environ., 51, 21-28, doi:10.1016/j.atmosenv.2012.01.056, 2012.

Huebert, B., Mingxing, W., and Weixiu, L.: Atmospheric nitrate, sulfate, ammonium and calcium concentrations in China, Tellus B, 40, 260-269, 1988.

Jacobson, M. Z.: Strong radiative heating due to the mixing state of black carbon in atmospheric aerosols, Nature, 409, 695-697, 2001.

Jacobson, M. Z.: Effects of Externally-Through-InternallyMixed Soot Inclusions within Clouds and Precipitation on Global Climate, J. Phys. Chem. A, 110, 6860-6873, doi:10.1021/jp056391r, 2006.

John, W., Wall, S. M., Ondo, J. L., and Winklmayr, W.: MODES IN THE SIZE DISTRIBUTIONS OF ATMOSPHERIC INORGANIC AEROSOL, Atmos. Environ. A-Gen., 24, 2349-2359, doi:10.1016/0960-1686(90)90327-j, 1990.

Jongejan, P., Bai, Y., Veltkamp, A., Wye, G., and Slaninaa, J.: An Automated Field Instrument for The Determination of Acidic Gases in Air, Int. J. Environ. An. Ch., 66, 241-251, 1995.

Kanakidou, M., Seinfeld, J. H., Pandis, S. N., Barnes, I., Dentener, F. J., Facchini, M. C., Van Dingenen, R., Ervens, B., Nenes, A., Nielsen, C. J., Swietlicki, E., Putaud, J. P., Balkanski, Y., Fuzzi, S., Horth, J., Moortgat, G. K., Winterhalter, R., Myhre, C. E. L., Tsigaridis, K., Vignati, E., Stephanou, E. G., and Wilson, J.: Organic aerosol and global climate modelling: a review, Atmos. Chem. Phys., 5, 1053-1123, doi:10.5194/acp-5-1053-2005, 2005.

Khalizov, A. F., Zhang, R., Zhang, D., Xue, H., Pagels, J., and McMurry, P. H.: Formation of highly hygroscopic soot aerosols upon internal mixing with sulfuric acid vapor, J. Geophys. Res.Atmos., 114, D05208, doi:10.1029/2008JD010595, 2009.

Koch, D. and Del Genio, A. D.: Black carbon semi-direct effects on cloud cover: review and synthesis, Atmos. Chem. Phys., 10, 7685-7696, doi:10.5194/acp-10-7685-2010, 2010.

Kondo, Y., Komazaki, Y., Miyazaki, Y., Moteki, N., Takegawa, N., Kodama, D., Deguchi, S., Nogami, M., Fukuda, M., Miyakawa, T., Morino, Y., Koike, M., Sakurai, H., and Ehara, K.: Temporal variations of elemental carbon in Tokyo, J. Geophys. Res.Atmos., 111, D12205, doi:10.1029/2005JD006257, 2006.

Laborde, M., Schnaiter, M., Linke, C., Saathoff, H., Naumann, K.H., Möhler, O., Berlenz, S., Wagner, U., Taylor, J. W., Liu, D., Flynn, M., Allan, J. D., Coe, H., Heimerl, K., Dahlkötter, F., Weinzierl, B., Wollny, A. G., Zanatta, M., Cozic, J., Laj, P., Hitzenberger, R., Schwarz, J. P., and Gysel, M.: Single Particle Soot Photometer intercomparison at the AIDA chamber, Atmos. Meas. Tech., 5, 3077-3097, doi:10.5194/amt-5-3077-2012, 2012.

Laborde, M., Crippa, M., Tritscher, T., Jurányi, Z., Decarlo, P. F., Temime-Roussel, B., Marchand, N., Eckhardt, S., Stohl, A., Baltensperger, U., Prévôt, A. S. H., Weingartner, E., and Gysel, M.: Black carbon physical properties and mixing state in the European megacity Paris, Atmos. Chem. Phys., 13, 5831-5856, doi:10.5194/acp-13-5831-2013, 2013.

Lack, D. A. and Cappa, C. D.: Impact of brown and clear carbon on light absorption enhancement, single scatter albedo and ab- 
sorption wavelength dependence of black carbon, Atmos. Chem. Phys., 10, 4207-4220, doi:10.5194/acp-10-4207-2010, 2010.

Lan, Z. J., Huang, X. F., Yu, K. Y., Sun, T. L., Zeng, L. W., and $\mathrm{Hu}, \mathrm{M}$. : Light absorption of black carbon aerosol and its enhancement by mixing state in an urban atmosphere in South China, Atmos. Environ., 69, 118-123, doi:10.1016/j.atmosenv.2012.12.009, 2013.

Lee, A. K. Y., Willis, M. D., Healy, R. M., Onasch, T. B., and Abbatt, J. P. D.: Mixing state of carbonaceous aerosol in an urban environment: single particle characterization using the soot particle aerosol mass spectrometer (SP-AMS), Atmos. Chem. Phys., 15, 1823-1841, doi:10.5194/acp-15-1823-2015, 2015a.

Lee, A. K. Y., Willis, M. D., Healy, R. M., Wang, J. M., Jeong, C.H., Wenger, J. C., Evans, G. J., and Abbatt, J. P. D.: Single particle characterization of biomass burning organic aerosol (BBOA): evidence for non-uniform mixing of high molecular weight organics and potassium, Atmos. Chem. Phys. Discuss., 15, $32157-$ 32183, doi:10.5194/acpd-15-32157-2015, 2015 b.

Li, L., Huang, Z., Dong, J., Li, M., Gao, W., Nian, H., Fu, Z., Zhang, G., Bi, X., Cheng, P., and Zhou, Z.: Real time bipolar time-of-flight mass spectrometer for analyzing single aerosol particles, Int. J. Mass Spectrom., 303, 118-124, doi:10.1016/j.ijms.2011.01.017, 2011.

Li, L., Tan, G. B., Zhang, L., Fu, Z., Nian, H. Q., Huang, Z. X., Zhou, Z., and Li, M.: Analysis of Diesel Exhaust Particles Using Single Particle Aerosol Mass Spectrometry, Chinese J. Anal. Chem., 41, 1831-1836, doi:10.3724/SP.J.1096.2013.30545, 2013.

Liu, D., Allan, J., Whitehead, J., Young, D., Flynn, M., Coe, H., McFiggans, G., Fleming, Z. L., and Bandy, B.: Ambient black carbon particle hygroscopic properties controlled by mixing state and composition, Atmos. Chem. Phys., 13, 2015-2029, doi:10.5194/acp-13-2015-2013, 2013.

Liu, D., Allan, J. D., Young, D. E., Coe, H., Beddows, D., Fleming, Z. L., Flynn, M. J., Gallagher, M. W., Harrison, R. M., Lee, J., Prevot, A. S. H., Taylor, J. W., Yin, J., Williams, P. I., and Zotter, P.: Size distribution, mixing state and source apportionment of black carbon aerosol in London during wintertime, Atmos. Chem. Phys., 14, 10061-10084, doi:10.5194/acp14-10061-2014, 2014.

Matsui, H., Koike, M., Kondo, Y., Moteki, N., Fast, J. D., and Zaveri, R. A.: Development and validation of a black carbon mixing state resolved three-dimensional model: Aging processes and radiative impact, J. Geophys. Res.-Atmos., 118, 2304-2326, doi:10.1029/2012JD018446, 2013.

McMeeking, G. R., Hamburger, T., Liu, D., Flynn, M., Morgan, W. T., Northway, M., Highwood, E. J., Krejci, R., Allan, J. D., Minikin, A., and Coe, H.: Black carbon measurements in the boundary layer over western and northern Europe, Atmos. Chem. Phys., 10, 9393-9414, doi:10.5194/acp-10-9393-2010, 2010.

McMeeking, G. R., Morgan, W. T., Flynn, M., Highwood, E. J., Turnbull, K., Haywood, J., and Coe, H.: Black carbon aerosol mixing state, organic aerosols and aerosol optical properties over the United Kingdom, Atmos. Chem. Phys., 11, 9037-9052, doi:10.5194/acp-11-9037-2011, 2011.

Moffet, R. C. and Prather, K. A.: In-situ measurements of the mixing state and optical properties of soot with implications for radiative forcing estimates, P. Natl. Acad. Sci. USA, 106, 1187211877, doi:10.1073/pnas.0900040106, 2009.
Moffet, R. C., de Foy, B., Molina, L. T., Molina, M. J., and Prather, K. A.: Measurement of ambient aerosols in northern Mexico City by single particle mass spectrometry, Atmos. Chem. Phys., 8, 4499-4516, doi:10.5194/acp-8-4499-2008, 2008.

Moteki, N. and Kondo, Y.: Dependence of laser-induced incandescence on physical properties of black carbon aerosols: Measurements and theoretical interpretation, Aerosol Sci. Tech., 44, 663675, 2010.

Moteki, N., Kondo, Y., Miyazaki, Y., Takegawa, N., Komazaki, Y., Kurata, G., Shirai, T., Blake, D., Miyakawa, T., and Koike, M.: Evolution of mixing state of black carbon particles: Aircraft measurements over the western Pacific in March 2004, Geophys. Res. Lett., 34, L11803, doi:10.1029/2006GL028943, 2007.

Moteki, N., Kondo, Y., and Nakamura, S.: Method to measure refractive indices of small nonspherical particles: Application to black carbon particles, J. Aerosol Sci., 41, 513-521, doi:10.1016/j.jaerosci.2010.02.013, 2010.

Moteki, N., Kondo, Y., Oshima, N., Takegawa, N., Koike, M., Kita, K., Matsui, H., and Kajino, M.: Size dependence of wet removal of black carbon aerosols during transport from the boundary layer to the free troposphere, Geophys. Res. Lett., 39, L13802, doi:10.1029/2012GL052034, 2012.

Moteki, N., Kondo, Y., and Adachi, K.: Identification by singleparticle soot photometer of black carbon particles attached to other particles: Laboratory experiments and ground observations in Tokyo, J. Geophys. Res.-Atmos., 119, 1031-1043, 2014.

Onasch, T. B., Trimborn, A., Fortner, E. C., Jayne, J. T., Kok, G. L., Williams, L. R., Davidovits, P., and Worsnop, D. R. Soot Particle Aerosol Mass Spectrometer: Development, Validation, and Initial Application, Aerosol Sci. Tech., 46, 804-817, doi:10.1080/02786826.2012.663948, 2012.

Petzold, A., Ogren, J. A., Fiebig, M., Laj, P., Li, S.-M., Baltensperger, U., Holzer-Popp, T., Kinne, S., Pappalardo, G., Sugimoto, N., Wehrli, C., Wiedensohler, A., and Zhang, X.-Y.: Recommendations for reporting "black carbon" measurements, Atmos. Chem. Phys., 13, 8365-8379, doi:10.5194/acp-13-83652013, 2013.

Pöschl, U.: Atmospheric aerosols: Composition, transformation, climate and health effects, Angew. Chem. Int. Edit., 44, 75207540, 2005.

Ramanathan, V. and Carmichael, G.: Global and regional climate changes due to black carbon, Nat. Geosci., 1, 221-227, 2008.

Reddington, C. L., McMeeking, G., Mann, G. W., Coe, H., Frontoso, M. G., Liu, D., Flynn, M., Spracklen, D. V., and Carslaw, K. S.: The mass and number size distributions of black carbon aerosol over Europe, Atmos. Chem. Phys., 13, 4917-4939, doi:10.5194/acp-13-4917-2013, 2013.

Riemer, N., Vogel, H., and Vogel, B.: Soot aging time scales in polluted regions during day and night, Atmos. Chem. Phys., 4, 1885-1893, doi:10.5194/acp-4-1885-2004, 2004.

Sahu, L. K., Kondo, Y., Moteki, N., Takegawa, N., Zhao, Y., Cubison, M. J., Jimenez, J. L., Vay, S., Diskin, G. S., Wisthaler, A., Mikoviny, T., Huey, L. G., Weinheimer, A. J., and Knapp, D. J.: Emission characteristics of black carbon in anthropogenic and biomass burning plumes over California during ARCTAS-CARB 2008, J. Geophys. Res.-Atmos., 117, D16302, doi:10.1029/2011jd017401, 2012.

Schnaiter, M., Linke, C., Mohler, O., Naumann, K. H., Saathoff, H., Wagner, R., Schurath, U., and Wehner, B.: Absorp- 
tion amplification of black carbon internally mixed with secondary organic aerosol, J. Geophys. Res.-Atmos., 110, D19204, doi:10.1029/2005jd006046, 2005.

Schwarz, J. P., Gao, R. S., Fahey, D. W., Thomson, D. S., Watts, L. A., Wilson, J. C., Reeves, J. M., Darbeheshti, M., Baumgardner, D. G., Kok, G. L., Chung, S. H., Schulz, M., Hendricks, J., Lauer, A., Karcher, B., Slowik, J. G., Rosenlof, K. H., Thompson, T. L., Langford, A. O., Loewenstein, M., and Aikin, K. C.: Single-particle measurements of midlatitude black carbon and light-scattering aerosols from the boundary layer to the lower stratosphere, J. Geophys. Res.-Atmos., 111, D16207, doi:10.1029/2006jd007076, 2006.

Schwarz, J. P., Gao, R. S., Spackman, J. R., Watts, L. A., Thomson, D. S., Fahey, D. W., Ryerson, T. B., Peischl, J., Holloway, J. S., Trainer, M., Frost, G. J., Baynard, T., Lack, D. A., de Gouw, J. A., Warneke, C., and Del Negro, L. A.: Measurement of the mixing state, mass, and optical size of individual black carbon particles in urban and biomass burning emissions, Geophys. Res. Lett., 35, L13810, doi:10.1029/2008g1033968, 2008.

Schwarz, J. P., Spackman, J. R., Gao, R. S., Perring, A. E., Cross, E., Onasch, T. B., Ahern, A., Wrobel, W., Davidovits, P., Olfert, J., Dubey, M. K., Mazzoleni, C., and Fahey, D. W.: The Detection Efficiency of the Single Particle Soot Photometer, Aerosol Sci. Technol., 44, 612-628, doi:10.1080/02786826.2010.481298, 2010.

Seinfeld, J. H. and Pandis, S. N.: Atmospheric chemistry and physics: from air pollution to climate change, John Wiley \& Sons, 2012.

Shiraiwa, M., Kondo, Y., Iwamoto, T., and Kita, K.: Amplification of light absorption of black carbon by organic coating, Aerosol Sci. Tech., 44, 46-54, doi:10.1080/02786820903357686, 2010.

Song, X. H., Hopke, P. K., Fergenson, D. P., and Prather, K. A.: Classification of single particles analyzed by ATOFMS using an artificial neural network, ART-2A, Anal. Chem., 71, 860-865, doi:10.1021/ac9809682, 1999.

Soto-García, L. L., Andreae, M. O., Andreae, T. W., Artaxo, P., Maenhaut, W., Kirchstetter, T., Novakov, T., Chow, J. C., and Mayol-Bracero, O. L.: Evaluation of the carbon content of aerosols from the burning of biomass in the Brazilian Amazon using thermal, optical and thermal-optical analysis methods, Atmos. Chem. Phys., 11, 4425-4444, doi:10.5194/acp-11-44252011, 2011.

Stephens, M., Turner, N., and Sandberg, J.: Particle identification by laser-induced incandescence in a solid-state laser cavity, Appl. Optics, 42, 3726-3736, doi:10.1364/ao.42.003726, 2003.

Takahama, S., Russell, L. M., Shores, C. A., Marr, L. C., Zheng, J., Levy, M., Zhang, R., Castillo, E., Rodriguez-Ventura, J. G., Quintana, P. J. E., Subramanian, R., Zavala, M., and Molina, L. T.: Diesel vehicle and urban burning contributions to black carbon concentrations and size distributions in Tijuana, Mexico, during the Cal-Mex 2010 campaign, Atmos. Environ., 88, 341352, doi:10.1016/j.atmosenv.2013.09.057, 2014.
Taylor, J. W., Allan, J. D., Liu, D., Flynn, M., Weber, R., Zhang, X., Lefer, B. L., Grossberg, N., Flynn, J., and Coe, H.: Assessment of the sensitivity of core/shell parameters derived using the single-particle soot photometer to density and refractive index, Atmos. Meas. Tech., 8, 1701-1718, doi:10.5194/amt-81701-2015, 2015.

Wang, Q., Zhuang, G., Huang, K., Liu, T., Deng, C., Xu, J., Lin, Y., Guo, Z., Chen, Y., Fu, Q., Fu, J. S., and Chen, J.: Probing the severe haze pollution in three typical regions of China: Characteristics, sources and regional impacts, Atmos. Environ., 120, 76-88, doi:10.1016/j.atmosenv.2015.08.076, 2015.

Wang, X., Ye, X., Chen, H., Chen, J., Yang, X., and Gross, D. S.: Online hygroscopicity and chemical measurement of urban aerosol in Shanghai, China, Atmos. Environ., 95, 318-326, doi:10.1016/j.atmosenv.2014.06.051, 2014.

Willis, M. D., Healy, R. M., Riemer, N., West, M., Wang, J. M., Jeong, C.-H., Wenger, J. C., Evans, G. J., Abbatt, J. P. D., and Lee, A. K. Y.: Quantification of black carbon mixing state from traffic: implications for aerosol optical properties, Atmos. Chem. Phys., 16, 4693-4706, doi:10.5194/acp-16-4693-2016, 2016.

Yao, X., Chan, C. K., Fang, M., Cadle, S., Chan, T., Mulawa, P., He, K., and Ye, B.: The water-soluble ionic composition of $\mathrm{PM}_{2.5}$ in Shanghai and Beijing, China, Atmos. Environ., 36, 4223-4234, doi:10.1016/S1352-2310(02)00342-4, 2002.

Zhang, G., Bi, X., He, J., Chen, D., Chan, L. Y., Xie, G., Wang, X., Sheng, G., Fu, J., and Zhou, Z.: Variation of secondary coatings associated with elemental carbon by single particle analysis, Atmos. Environ., 92, 162-170, doi:10.1016/j.atmosenv.2014.04.018, 2014.

Zhang, R., Khalizov, A. F., Pagels, J., Zhang, D., Xue, H., and McMurry, P. H.: Variability in morphology, hygroscopicity, and optical properties of soot aerosols during atmospheric processing, P. Natl. Acad. Sci., 105, 10291-10296, doi:10.1073/pnas.0804860105, 2008.

Zhang, Y. X., Zhang, Q., Cheng, Y. F., Su, H., Kecorius, S., Wang, Z. B., Wu, Z. J., Hu, M., Zhu, T., Wiedensohler, A., and He, K. B.: Measuring morphology and density of internally mixed black carbon with SP2 and VTDMA: new insight to absorption enhancement of black carbon in the atmosphere, Atmos. Meas. Tech. Discuss., 8, 12025-12050, doi:10.5194/amtd8-12025-2015, 2015. 